\title{
Encouraging the Startup Spirit of Students: Implications and Solutions
}

\author{
Than Thanh Son Nguyen Manh Cuong ${ }^{*} \quad$ Bui Thi Thu Loan \\ Business Management Faculty, Hanoi University of Industry, 298 Cau Dien Street, \\ North Tu Liem District, Hanoi, Vietnam
}

\begin{abstract}
Starting a business by the establishment of a new business or a new business project plays an important role in the economic development of each country. Promoting the entrepreneurial spirit of students at universities is the basis for contributing to the success of start-up countries. This study provides empirical evidence of factors affecting student entrepreneurship based on survey data of a sample of 321 students. The study results clarify the factors affecting the initial entrepreneurial intention of students, and are an important foundation for starting-up in the future. Since then, the findings from regression analysis are the basis to imply some solutions from the school and the Government to promote the entrepreneurial spirit of young people.
\end{abstract}

Keywords: Entrepreneurship intention; Social-education environment; Taking risk; Student

DOI: $10.7176 /$ RJFA/11-4-07

Publication date: February $29^{\text {th }} 2020$

\section{Introduction}

Changing the perception of career in the direction of doing a good job with any assigned tasks to mastering business is essential in creating success for a startup country. In the context of Vietnam's economy, with historical characteristics, the younger generation still tends to study and achieve the best results to get stable job opportunities and / or achieve high income instead of orientation to start a business to create jobs for oneself, contributing to increasing employment in society.

Currently, although the awareness of entrepreneurship among young people has changed in a positive way, in order to perfect the start-up ecosystem, to encourage entrepreneurship, motivating students to self-develop their sense of self-development and create a driving force for economic development is necessary. This issue has been mentioned a lot in both developed countries as well as Asian countries, such as Adewal et al (2016), Castiglione (2013), Wasihun (2015), David et al (2016). In Vietnam, research on this topic is not plentiful. Existing studies mainly focus on the start up intentions of entrepreneurs, who have certain experience and success in their work, such as Phillis and Readern (2007), Choi et al (2012), Le Quan (2007, 2010). The subjects of these studies cannot represent the young people currently attending universities because of the differences in social experience as well as work experience and financial background. A number of studies have been done on a sample of students from a particular school or field, such as Nghi Nguyen et al (2016), Trang Doan (2018), Tu Phan and Huy Tran (2017), Quang Nguyen (2017), providing information on related issues but lacking representation to population.

Some other studies performed by Anh Nguyen (2014), Thuy Nguyen (2014), have implemented on a more representative sample. However, in the context of economic changes, especially the government start up programs and necessary construction to improve the startup ecosystem in Vietnam since 2015, the frame of awareness, attitudes and concepts based on subjective norms for the startup intention of young people may have been affected. Therefore, to promote the entrepreneurial spirit of young people in the current start-up countries, more evidence of the factors affecting their start-up intentions is needed, typically from students who are study at universities.

With the approach as mentioned above, the study carried out quantitative analysis of factors affecting students' intention to start a business based on the Theory of planned behavior (TPB) by Ajzen (1991) as a basis for this analysis.

\section{Literature review}

The theory of planed behaviour (TPB) by Ajzen (1991), explains and predicts the behavior applied in different research areas in explaining and predicting the behavior. This theory was developed based on the theory of reasoned action - TRA, which states that individual's intention to perform a certain behavior is influenced by three factors, namely: Attitude; subjective norms and perceived behavioral control. TPB theory has been further developed and expanded by many researchers to explain and predict human behavior in specific contexts, such as: Chang (1998), Choo et al. (2004), provided Experimental evidence of the positive effects of Attitude, subjective norms and perceived behavior control on the intention to implement behaviors; green consumption behavior by Huong Pham (2014), Mai Nguyen et al (2016); Long Pham's intention to use internet banking (2014), Chin Ho Lin (2011). Therefore, the TPB theoretical framework is also used in studying students' intention to start a business. - Start up intention

In this study, based on the approach of TPB theory, the idea of starting a business is understood as the individual's 
intention to own the business in his work. This is the first step in the process of creating a particular business project, becoming an entrepreneur. At that time, the higher the intention of starting a business, the greater the ability to conduct business ownership is. Therefore, studying the intention to implement the start-up behavior of students aims to identify the factors affecting the intention of starting a business, as a basis to encourage entrepreneurship spirit among young people in Vietnam currently. On that basis, the author hypothesizes the following:

Hypothesis H1: Attitude has a positive relationship with the start-up intention of student

Hypothesis H2: Subjective norms has a positive relationship with students' intention to start a business;

Hypothesis H3: Perceived behaviour control has a positive relationship with the student's intention to start a business.

\section{- The orientation to dare to take risks, the role of educational environment and practical experiences}

Entrepreneurship orientation (EO) is mentioned in the studies of Keh et al. (2007), Covin and Sevin (1989), Miller and Friesen (1982). According to these studies, the courage to accept risk is an aspect representing individual choices in terms of uncertain factors. Moriano (2012), argued that the decision to become an entrepreneur is a deliberate and carefully considered decision. However, for young people, the need to explore their own limitations by self-employment can overcome considerations based on available experiences.

In fact, students are motivated to start up by passion and grasping opportunities rather than based on previous work experience and entrepreneurship skills, because, in fact, they are still in their study period, as well as accumulation of knowledge and experience. Therefore, individuals who have an incentive to start up a business early with greater mastery are viewed as an aspect of entrepreneurial orientation among young people and vice versa, those who fear failure are risk-averse individuals. Therefore, perceiving the risk of failure becomes an important factor in the decision to establish a new business.

The issue above relates to funding and exploring market demands. David and colleagues (2016), argue that starting a business is risky, so within a certain limit, risk aversion affects the behavior of each individual. The most risk-averse individuals will reduce their interest and motivation to start a new business by limiting their ability to assess and detect opportunities. Adewale (2016), also showed that the opportunity for experience and training is a process that helps individuals achieve the skills needed to create confidence and independence. Students can leverage and develop business ideas and capture market opportunities for certain products and services, which are important contributors to the growth and survival of small young businesses (Hellriegel et al., 2008).

On that basis, the author proposed hypotheses H4, H5 and H6 as follow:

Hypothesis H4: The tendency to avoid risk has a negative impact on students' intention to start a new business.

Hypothesis H5: The educational environment has a positive impact on students' intention to start a new business; and

Hypothesis H6: Experience opportunities has a positive impact on students' intention to start a new business. With the above hypotheses based on the TPB theoretical framework of Ajzen (1991), we built a model for this study with six independent variables and two control variables to determine the impact of factors on the student's intention to start a business (Figure 1).

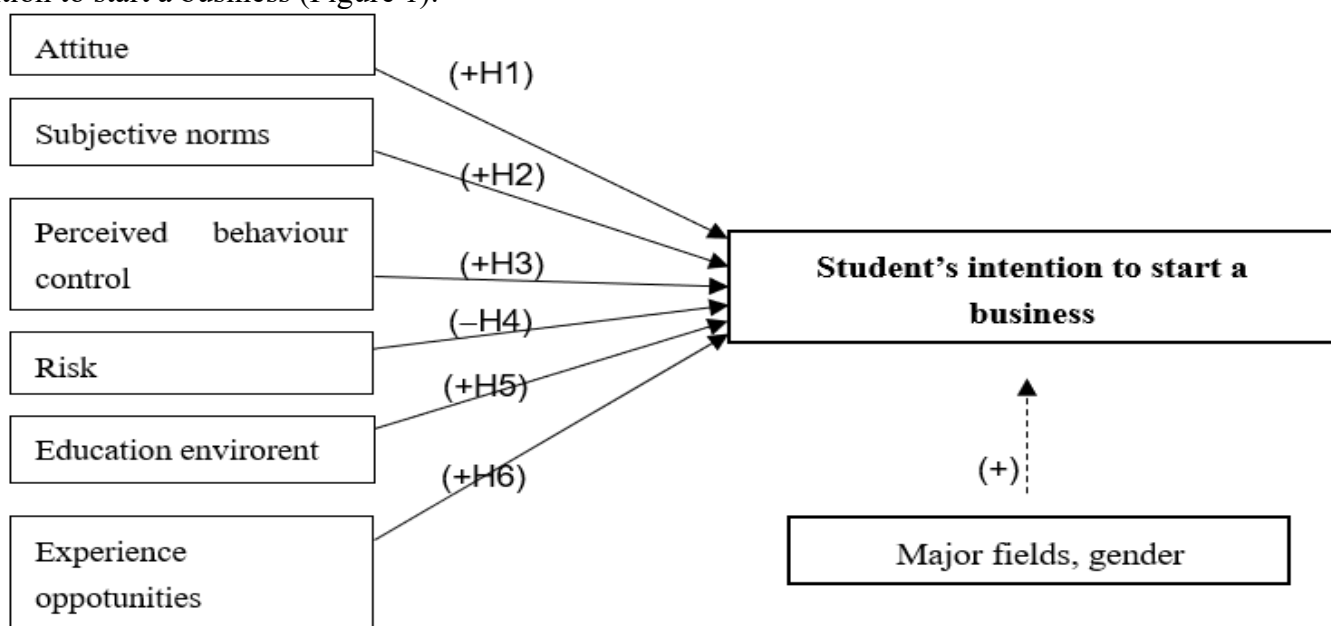

Figure 1. Research model

\section{Methodology}

Before conducting the regression analysis, we conducted a qualitative study to preliminarily check the 
appropriateness of the variables involved in the model, as well as make necessary adjustments to ensure compliance with research context at the present time. Preliminary qualitative research through in-depth interviews was conducted with 14 students in the third and last year. The average length of interviews was from 25 to 30 minutes. The content of interviews is based on the interview guide, in which, the students interviewed includes: 06 students participating in competitions related to startup ideas for students, 01 student has been mastering a small business project and 07 other students.

As mentioned above, in-depth interviews were conducted to initially examine the appropriateness of independent variables affecting students' intention to start a business, to preliminarily identify the relationship between variables in the model. Preliminary qualitative research results support the research model proposed above. Most students interviewed said that the opportunity to experience and learning environment plays an important role in the intention of establishing a business. However, students who want to work at companies after graduation say they need time (5-7 years) to accumulate experience and capital. At the same time, they also stated that not everyone wants to start a business, and that a stable job with a high income is also a way to prove their ability. In contrast, the number of students with strong start-up intentions are those who have been/are learning or participating in start-up clubs and start-up projects. They think that looking for a start-up opportunity by managing a business is satisfies their passion and that they need to challenge themselves at a young age to both gain experience and learn. These students said, "Starting a business is to face risks, but the risk does not necessarily lead to failure; they may even be an opportunity."

The process of applying quantitative research methods, analyzing primary data obtained from a survey sample of 321 students studying at schools: Hanoi University of Industry, National Economics University, Electricity University, Foreign Trade University, and the Academy of Finance in Hanoi utilized the software SPSS version 22. Survey subjects are university students in the third and last year studying engineering or economics. The number of questionnaires issued are 356 (sent directly or via Google survey form). The number of responses were 330. The valid votes used in regression analysis were 321 votes, of which men accounted for $47.4 \%$ and women accounted for $52.6 \%$. The survey was carried out through using questionnaires with the Likert scale of 5 points, in which 1 point equals "strongly disagree" and 5 points equal "strongly agree". The questions for the scales in the study were built on the basis of the results in the previous studies of Ajzen (1991, 2002), Holak and Leman (1990), Nguyen Thi Tuyet Mai (2016), Adewal et al (2016), combined with the adjustments according to the preliminary qualitative research results carried out earlier. Some variables and scales are described in details in Table 1.

Table 1: The scale of some variables

\begin{tabular}{|c|c|c|c|c|}
\hline \multicolumn{2}{|c|}{ Code } & Items & Scale & Recourse \\
\hline \multirow{5}{*}{$\begin{array}{l}\text { Attitude } \\
\text { (TD) }\end{array}$} & TD1 & $\begin{array}{l}\text { 1. Starting up is a good intention for the } \\
\text { young nowadays. }\end{array}$ & \multirow{5}{*}{$\begin{array}{l}\text { Likert } \\
1-5\end{array}$} & \multirow{5}{*}{$\begin{array}{l}\text { Chan and Chen (2001), } \\
\text { Mai Nguyen (2016), Holak } \\
\text { and Leman (1990), Thuy } \\
\text { Nguyen et al (2017), } \\
\text { Lauzikas and Dailydaite } \\
\text { (2016), Begley and Tan } \\
\text { (2001), Yen Nguyen } \\
\text { (2011) }\end{array}$} \\
\hline & TD 2 & $\begin{array}{l}\text { 2. I absolutely support the idea of starting } \\
\text { up from young people. }\end{array}$ & & \\
\hline & TD 3 & $\begin{array}{l}\text { 3. Starting up creates a good personal image } \\
\text { for the individual. }\end{array}$ & & \\
\hline & TD 4 & 4. I like the idea of starting up. & & \\
\hline & TD 5 & 5. Business is my passion. & & \\
\hline \multirow{4}{*}{$\begin{array}{l}\text { Risk } \\
\text { (RR) }\end{array}$} & RR1 & $\begin{array}{l}\text { 1. When choosing between business } \\
\text { opportunities and having a stable job, I tend } \\
\text { to be considerate to reduce possible } \\
\text { mistakes or choices that I might later regret. }\end{array}$ & \multirow{4}{*}{$\begin{array}{c}\text { Likert } \\
1-5\end{array}$} & \multirow{4}{*}{$\begin{array}{l}\text { Holak and Leman (1990), } \\
\text { Mai Nguyen (2016), } \\
\text { Adewal et al. (2016), Keh } \\
\text { et al. (2007) }\end{array}$} \\
\hline & RR2 & $\begin{array}{l}\text { 2. The worry of not having enough or losing } \\
\text { capital negatively affects my intention of } \\
\text { starting up. }\end{array}$ & & \\
\hline & RR3 & $\begin{array}{l}\text { 3. I think a lack of experience and capital is } \\
\text { a risk in running a business, preventing me } \\
\text { from successfully managing my startup. }\end{array}$ & & \\
\hline & RR4 & $\begin{array}{l}\text { 4. Due to certain characteristics of the } \\
\text { business environment, I need time to } \\
\text { acquire better knowledge and practice } \\
\text { before thinking about starting up. }\end{array}$ & & \\
\hline \multirow{3}{*}{$\begin{array}{l}\text { The startup } \\
\text { Intention } \\
\text { of students } \\
\text { (YD) }\end{array}$} & YD1 & $\begin{array}{l}\text { 1. I will consider the idea of starting up in } \\
\text { the time to come. }\end{array}$ & \multirow{3}{*}{$\begin{array}{l}\text { Likert } \\
1-5\end{array}$} & \multirow{3}{*}{$\begin{array}{l}\text { Keh et al (2007), Mai } \\
\text { Nguyen (2016) }\end{array}$} \\
\hline & YD2 & 2. Starting up is my life goal. & & \\
\hline & YD3 & $\begin{array}{l}\text { 3.I want financial independence and the } \\
\text { reputation of owning a business. }\end{array}$ & & \\
\hline
\end{tabular}




\section{Results and Discussion}

- The result of analyzing reality of scale

The result of analyzing the reliability of the scale (Table2), Cronbach Alpha, showed that Cronbach Alpha results of 6 factors gained high value. All of these values were higher than 0.8, thus scales are reliable (Hair at el, 1998). Besides, the data used in this analysis is suitable in factor analysis, KMO value equal $0.764(>0.5)$. The result of Exploratory factor analysis (EFA) based on the report of average variance extracted and the Factor of results loading illustrated that the scales in this study is significant with average variance extracted was $70.34 \%$ and factor loading were higher than 0.5 . The result of factor rotated matrix also showed the stability among groups of examined scales.

Table 2: The result of analyzing reality of scale

\begin{tabular}{|l|c|c|}
\hline \multicolumn{1}{|c|}{ Variables } & Cronbach Alpha & N of Items \\
\hline Attitude & 0,890 & 5 \\
\hline Subjective norms & 0,900 & 4 \\
\hline Perceived behavior control & 0,823 & 6 \\
\hline Learning environment & 0,805 & 5 \\
\hline Risk & 0,887 & 3 \\
\hline Experience opportunities & 0,868 & 0,675 \\
\hline KMO & \multicolumn{2}{|c|}{ Sig =0,000 } \\
\hline Bartlett's Test & \multicolumn{2}{|c|}{ Source: Author's Computation }
\end{tabular}

Estimated function:

\section{- The results of regression analysis}

The results of multiple regression analysis (Table 3) show that the research model is appropriate, statistically significant with $\mathrm{F}=79.09 ; \mathrm{p}<0.01$. The factors of the model can explain $66.74 \%$ of the startup intention of students. The model does not encounter the problems of multicollinearity (VIF coefficient less than 5) and selfcorrelation (Dubin-Watson coefficient is 2.035).

Table 3. The results of regression analysis factors affecting the startup intention of students

\begin{tabular}{|c|c|c|c|c|c|c|c|}
\hline \multicolumn{8}{|c|}{ Coefficients } \\
\hline \multirow{2}{*}{ Model } & \multicolumn{2}{|c|}{$\begin{array}{c}\text { Unstandardized } \\
\text { Coefficients }\end{array}$} & \multirow{2}{*}{$\begin{array}{c}\begin{array}{c}\text { Standardized } \\
\text { Coefficients }\end{array} \\
\text { Beta }\end{array}$} & \multirow{2}{*}{$\mathbf{t}$} & \multirow{2}{*}{ Sig. } & \multicolumn{2}{|c|}{$\begin{array}{c}\text { Collinearity } \\
\text { Statistics } \\
\end{array}$} \\
\hline & B & $\begin{array}{l}\text { Std. } \\
\text { Error }\end{array}$ & & & & Tolerance & VIF \\
\hline (Constant) & 3.140 & 0.259 & & 12.110 & 0.000 & & \\
\hline Attitude & 0.065 & 0.028 & 0.086 & 2.360 & 0.019 & 0.792 & 1.262 \\
\hline Subjective norms & 0.120 & 0.026 & 0.156 & 4.538 & 0.000 & 0.890 & 1.123 \\
\hline $\begin{array}{l}\text { Perceived behavior } \\
\text { control }\end{array}$ & 0.138 & 0.031 & 0.185 & 4.405 & 0.000 & 0.596 & 1.677 \\
\hline Risk & -0.189 & 0.035 & -0.182 & -5.446 & 0.000 & 0.943 & 1.061 \\
\hline Opportunities & 0.093 & 0.036 & 0.110 & 2.583 & 0.010 & 0.580 & 1.724 \\
\hline $\begin{array}{c}\text { Learning } \\
\text { environments }\end{array}$ & 0.054 & 0.025 & 0.074 & 2.139 & 0.033 & 0.871 & 1.148 \\
\hline Major fields & -0.312 & 0.040 & -0.333 & -7.718 & 0.000 & 0.566 & 1.766 \\
\hline Gender & -0.278 & 0.041 & -0.283 & -6.769 & 0.000 & 0.602 & 1.660 \\
\hline Dobrin-Watson & \multicolumn{7}{|c|}{2.035} \\
\hline $\mathrm{R} 2$ & \multicolumn{2}{|c|}{$67.2 \%$} & \multicolumn{2}{|c|}{ R2 adjust } & \multicolumn{3}{|c|}{$66.74 \%$} \\
\hline
\end{tabular}

The results of the regression analysis show that the attitude has positive impact to start up intention of students $(\beta=0,86 ; p<0,05)$. The factors of subjective norms factor, perceived behavior control or usefulness awareness of service use also impact positively to the students' intention of running an own business (standardized coefficient 0,156 and 0.185 respectively, at $5 \%$ significance level).

The results of regression analysis also indicate that risk factors have negative effects on students' intention to start a business. This result is consistent with the findings in the study of Chin and Nguyen (2011), and similar to qualitative research results. This also shows that the start-up intentions of students who dare to face risks is higher. Risk aversion is a factor that has a strong influence on students' intention to start a business. The standardized coefficient is -0.182 at $5 \%$ significance level. Opportunities for experience and educational environment also affect students' intention to start a business at 5\% significance level. This result also gained support from research by David et al. (2016). Control variables to major fields and gender also affect students' intention to start a business. 


\section{- Discussion and policy implications}

The results of this study are similar to the results of some previous studies (Thuy Nguyen, 2014; Anh Nguyen, 2014), (i) assert that the factors of Attitude, subjective norms, perceived behavioral control have a positive effect on the students' intention to start up a business. At the same time, this study also showed (ii) risk aversion has a negative impact on students' intention to start a business. This result is similar to current practice in Vietnam, namely students in Northern Vietnam.

Although the economy has made positive changes in the direction of shifting to the private sector, the Government has also made moves to encourage and improve entrepreneurship. However, the desire to have a stable job at state-owned enterprises after graduation still exists in most students in Hanoi. On the contrary, students who dare to take risks, pursue their passions to assert themselves, are experienced with start-up projects and / or start-up programs that intend to start a stronger business. In addition, (iii) the education environment also influences students' intention to start up with extracurricular programs, start-up knowledge or entrepreneurship research case studies discussed in the process of sharing knowledge. The test results also showed that, (iv) the control factor of the major fields and gender also has a certain influence on students' intention of starting a business. Students of Business Administration, Finance has a larger tendency to develop startup intentions rather than students of engineering and technological fields.

Based on the above research results, the author proposes some recommendations to promote the entrepreneurial spirit of students as follows:

First, the Government should increase their support and improve the entrepreneurial ecosystem for students. Capital support, a government advisory package for start-ups, and related information should be more strongly communicated to young people. When psychological barriers and risk aversion are removed, the desire to pursue a strong career will be boosted.

Second, the start-up movement through startup projects on business ideas, a startup club connecting students is really necessary in the higher education environment. This has been proven successful in Singapore or Israel. Start-up courses should also be included in the curriculum at current universities. Experience throughout the world indicates that the education policies of starting up at universities plays an important role in transforming students into potential entrepreneurs (Daewal, 2016). The formation of small businesses in universities, researchapplication-technology transfer groups, and business incubators create opportunities for students to gain business experience, increase practical knowledge, thereby, help students identify opportunities and participate in start-up networks. This is a problem that universities in Hanoi in particular and in Vietnam in general need to consider solving.

\section{Conclusion and Policy implications}

On the basis of inheriting the TPB theory, through quantitative research methods, this study has evaluated and measured the level of the influence of factors (Attitude; Subjective norms; Perceived behavior control; Risks, opportunities for experience, educational environment, major fields, gender) on students' intention to start a business. However, the scope and subjects of the survey in this study are limited, only in some universities in the city of Hanoi, so the next research direction on this topic will expand the scope of research; or direct attention to the entrepreneurial behavior of graduates.

\section{References}

Adewale A, Adekiya a, Fatima Ibrahim (2016), "Entrepreneurship intention among students. The antecedent role of culture and entrepreneurship training and development", The International Journal of Management Education, pp 116- 132.

Ajzen, I., (1991), “The theory of planned behaviour", Organizational Behavior and Human Decision Processes.

Bereket Mamo Buli Wasihun Mohammed Yesuf. Determinants of entrepreneurial intentions: Technical-vocational education and training students in Ethiopia, Education and Training, 57(8/9):891 - 907

Castiglione C., Licciardello O., Rampullo A.b, Campione, C "Liquid modernity and entrepreneurship orientation in university Students", Procedia - Social and Behavioral Sciences, 84, 9 pp.1250-1254

Chang, M.K. (1998), 'Predicting unethical behavior: A comparison of the theory of reasoned action and the theory of planned behavior', Journal of Business Ethics, 17, pp.1825-1834.

Chinho Lin (2011), "Exploring E-payment adoption in Vietnam and Taiwan”, Journal of Computer Information Systems.

Choi, Yang- Lim, Ha, Kyu- Soo (2012), "Factors affecting startup intention of retired office- workers", Journal of Digital Convergence, pp 195-212.

Choo, H., Chung, J.E. \& Pysarchik, D.T. (2004), “Antecedents to new food product purchasing behaviour among innovator groups in India”, European Journal of Marketing, 38 (5/6), pp.608-625.

Covin, J.G., and Slevin, D.P (1998), "Strategic Management of Small Firms in Hostile and Benign Enviroment", Strategic Managerment Journal, 10,pp.75-87 
David Urbano et al. (2016), "Institutional determinants of student employer entrepreneurs at Catalan universities", Technological Forecasting and Social Change, 123, pp.271-282

Doan Thi Thu Trang và Le Hieu Hoc (2017), "Factors affecting the intention to start engineering students: Research Hanoi University of Science and Technology", External Economic Review.

E De Pillis, KK Reardon (2007), "Career Development International”, emeraldinsight.com

Hair et al. (1998), "Multivariate Data Analysis (5thed.)", Prentice-Hall, Inc. Upper Saddle River, New Jersey.

Hellriegel et al. (2008), "Management (secound ed.), South African, Oxford: Oxford University Press

Holak (1990), "Purchase intentions and the dimensions of innovation: An exploratory model", Journal of Product Innovation and Management, 7(1), pp.59-73.

Keh et al. (2007), "The efects of Entrepreneurial Ỏrientation and Marketing Information on the Performance of SMEs", Jounal of Business Venturing, 22, pp.592-611

Le Quan (2010), "Researching start-up process of young Vietnamese entrepreneurs."

Long Pham (2014), "Intention to Use E-Banking in a Newly Emerging Country", International Journal of Enterprise Information Systems, 10(2), pp103-120

Miller, D, and Friesen, P.H (1982), "Innovation in convervative and entrepreneurial firms: two models of strategic momentum", Trategic Management Journal, 3, pp.1-25

Moriano, J.A. et al. (2012), “A cross-cultural approach to understanding entrepreneurial intention", Journal of Career Development, Vol. 39 No. 2, pp. 162-185.

Nguyen Quoc Nghi. et al. (2016), "Factors affecting the business start up intent of students in business administration at university in Can Tho city", Van Hien University Journal of Science.

Nguyen Thi Tuyet Mai. et al. (2016), "The impact of materialism on buying behavior of Vietnamese consumers in big cities"

Nguyen Thu Thuy, Nguyen Ngoc Huyen (2014), "Factors affecting the potential for starting a college business", Journal of Economic and development.

Nguyen Tuan Anh et al. (2014), "Research factors affecting students' intention to start a business in Ho Chi Minh City"

Pham Thi Lan Huong. et al. (2014), "Predicting young consumers' intention to buy green: The impact of cultural and psychological factors", Journal of Economic and development.

Phan Anh Tu, Tran Quoc Huy (2017), "Analysis of factors influencing entrepreneurial intention among students of Can Tho University of Technology", Can Tho University Journal of Science. 